Cronfa - Swansea University Open Access Repository

This is an author produced version of a paper published in:

Archives of Natural History

Cronfa URL for this paper:

http://cronfa.swan.ac.uk/Record/cronfa36767

\title{
Paper:
}

Raye, L. (2017). The Eurasian Lynx (Lynx Lynx) in early modern Scotland. Archives of Natural History, 44(2), 321333.

http://dx.doi.org/10.3366/anh.2017.0452

This item is brought to you by Swansea University. Any person downloading material is agreeing to abide by the terms of the repository licence. Copies of full text items may be used or reproduced in any format or medium, without prior permission for personal research or study, educational or non-commercial purposes only. The copyright for any work remains with the original author unless otherwise specified. The full-text must not be sold in any format or medium without the formal permission of the copyright holder.

Permission for multiple reproductions should be obtained from the original author.

Authors are personally responsible for adhering to copyright and publisher restrictions when uploading content to the repository. 
Author's Manuscript (published in Archives of Natural History 44.2: 321-333) by Edinburgh University Press - please see final version on EUP website. (https://doi.org/10.3366/anh.2017.0452)

\section{The Eurasian Lynx (Lynx lynx) in early modern Scotland}

L Raye

School of Welsh, Cardiff University, Colum Drive, Cardiff, CF10 3EG.

Abstract: Gesner's Historia Animalium preserves scholarly opinions from naturalists and humanists from across sixteenth century Europe. One such view comes from Bonar of Balice, south-east Poland. Bonar attests that although the European lynx (Lynx lynx) is common throughout central and eastern Europe, the best skins come from Sweden and, surprisingly, Scotland. After exploring evidence about who Bonar is and why he might have written to Gesner, this essay builds up two possible explanations for Bonar's opinion that lynx populations were present in sixteenth century Scotland:

(i) Either, Scotland's native populations of lynxes may have still been present in the sixteenth century: British lynx remains have been dated to the sixth century. The lynx could possibly have survived longer without being noticed in records if it was customarily called a 'cat', like other large felids. However, other than Bonar's attestation, there is only tentative positive evidence consistent with this interpretation; most importantly the ambiguous testimony of Robert Sibbald in 1684.

(ii) Or, Scotland may have 'tricked' Bonar by importing and then re-exporting fine, exotic furs: There is evidence that Scotland had a major fur industry. Lynx fur had a high status. Furs were commonly re-exported in the fourteenth century. Scots merchants often imported high-status furs like lynx into Poland in the sixteenth century, suggesting that Bonar had the highest possible chance of seeing Scottish-fashioned lynx furs.

This essay argues that, on balance of the evidence, the second interpretation is the stronger of the two, although the first is also possible.

Key words: Lynx, Gesner, Bonar, Early-Modern-Scotland, Wildlife-History.

In 1551 Conrad Gesner published the first part of his Historia Animalium. He intended the book to be a kind of literature review of previous scholarly research on animals (Pinon 2005). Gesner's volume was immediately popular, and remained well used for a century. What has not previously been emphasised, however, was the importance of the correspondence included from Gesner's contemporaries. As Ogilvie (2008: 34-38, 58) explains, like many other renaissance scholars in the 'Republic of Letters', Gesner had a vast network of learned colleagues across Europe who corresponded with him and sent him information and biological specimens. These were made up of those with a professional interest like doctors and apothecaries but also interested members of the renaissance literati including the gentry and aristocracy. 
Author's Manuscript (published in Archives of Natural History 44.2: 321-333) by Edinburgh University Press - please see final version on EUP website. (https://doi.org/10.3366/anh.2017.0452)

Our interest is on one such individual: Iohannis Bonar of Balice was a correspondent who first contacted Gesner after reading his Icones Animalium. Unfortunately, because he was not a source in the first edition, he is also not listed in Gesner's acknowledgement section ('Catlogvs Doctorvm') of Historia Animalium, nor have I found him listed in Gesner's Album Amoricum (See: Ogilvie 2008: 34). However, we can learn more about Bonar from his other pursuits. For example, I have found another letter by Bonar addressed to John Calvin, praising Calvin for his theology. In this letter (written 1556) we find more information. Bonar identifies himself as the pro-reformation castellan (castle-keeper) of 'Bieczan', (=Biecz, 90m from Kracow, Poland), but originally of Balice. In both this letter, and his letter to Gesner, he explains he is a liber baro. This should be understood to describe the nature of his job as a freiherr rather than his rank, since despite Biecz's early significance, it seems to have only been a minor castellany (Koneczny 1924: 2). Based on this letter and local records, Bonar's significance as a leading figure in the Polish reformation has long been recognised (Krasinski 1838: $143,279,335,359)[1]$.

Bonar was writing to Gesner regarding the portrayal of the lynx in Gesner's Icones Animalium. This was a short, pictures-only edition of Gesner's full text, Historia Animalium; initially (in 1553) Icones Animalium included just the woodcuts from the longer text. According to his letter, Bonar wanted to contribute a drawing of another species of lynx, plus a short note to this book. Although there is no date on Bonar's letter, given that he contributes a note, it is probable that he had seen the second (1560) edition of the Icones Animalium, which included text as well as plates and names. Gesner did not produce, as far as I am aware, a third edition of the book, but Bonar's complete note, again without the picture, was presented in the expanded 1602-3 edition of the full-length Historia Animalium.

I will provide his entire note from the Historia Animalium here since it is not lengthy and provides some interesting details:

In libro Iconum animalium, nullam fecisti mentionem Indicae vel Africanae Lyncis, praeterquam istius nostrae quae Germanico vocabulo Lox vocatur. Sed quia Plinius illius meminis induxit me authoritas tanti viri, ut $\&$ istam ad te depictam mitterem \& illius mentionem facerem(picturam nacti non sumus, forte amissa est)

Videtur enim cuius Plinius meminit multum differre a nostro lupo ceruario, qui cum sit maximus, vix attingit mediocrem lupum magnitudine. Ista vero Constantinopli depicta ferocem atque ingentem bestiam ostendit. Preterea istorum nostrorum Luxorum qui in 
Author's Manuscript (published in Archives of Natural History 44.2: 321-333) by Edinburgh University Press - please see final version on EUP website. (https://doi.org/10.3366/anh.2017.0452)

Moschouia, Lituania, Russia, Polonia, Hungaria, Germania capiuntur rari sunt admodum insignibus maculis in dorso conspersi, sed in ventre tantum.

Scotia tamen \& Suecia mittit omnium pulcherrimos isti. Vero de quibus loquor sunt maculis tam in dorso quam ventre aliisque membris pleni, nec sunt adeo villosi \& delicati vti nostrates cum habeant pilos asperos serosos \& breues. Insuper nostratum maculae sunt rotundae, istorum vero triangulares \& similes folio vocato kleblat.

(In the book Icones Animalium, you make no mention of the lynx of India or Africa, only of the one which in German we call the lox. But because Pliny remembered that one, this empowered me with the authority of such a man that I may send you this picture and you can make mention of it. (We can't find this picture, perhaps it is lost).

Indeed, it seems that that one which Pliny mentions differs greatly from our lupus cervarius which even at its greatest size scarcely attains the size of a mediocre wolf. Truly, that one of yours depicted in Constantinople is shown to be a ferocious and giant beast. Moreover, those loxes of ours which may be captured in Muscovy, Lithuania, Russia, Poland, Hungary and Germany, are rarely so greatly speckled with spots on the back, but only on the front.

However, Scotland and Sweden send the most beautiful of all of these. Of which, I say they are spotted both on the back and on the front and other parts, nor are they so furred and soft as ours though they have rough, serrated short hairs. Actually ours have round spots, these have triangular spots and similar to the leaf which you call klebat [clover]).

Confusingly, although Bonar's reason for writing is to introduce that exotic (ille) lynx of Africa and India, he is more interested in talking more about the native European lynxes he shares with Gesner (istorum nostorum) [2], the larger lupus cervarius and the smaller local lox. It's possible Bonar's ostensible reason for writing was a pretence to contact Gesner and talk about a favourite subject. Bonar signals his ability to speak German by his use of the words lox and klebat, but he writes in Latin. The ability to read and write fluent Latin was seen as the mark of a humanist scholar, and some corresponded in Latin even when they had a vernacular language in common with the addressee (Nauert 1979; Ogilvie 2008: 56). The existence of correspondence in Latin with a leading naturalist may have been a point of pride for Bonar.

However, from our perspective, Bonar's message is very informative. Most importantly, Bonar suggests that Scotland was famous for producing the most beautiful lox furs. They have beautiful and unusual spots, and the hair is not furry and soft like those from central and eastern Europe. The idea that this fur is beautiful but not smooth seems oddly contradictory. It is hard to ascertain details about historical fur preparation methods, but perhaps, fur in Poland was conventionally 'unhaired' of its prickly guard hairs. Veale (2003: $25-7$ ) suggests this procedure may not have been carried out on fur from England, where fur was just sheared, so perhaps the same is true of Scotland. 
Author's Manuscript (published in Archives of Natural History 44.2: 321-333) by Edinburgh University Press - please see final version on EUP website. (https://doi.org/10.3366/anh.2017.0452)

What are we to make of Bonar's comment about Scotland? First, it is important to point out that Bonar's opinion about Scotland may be well-informed. In the early modern period, there was a considerable British migrant and traveller community in eastern Europe, most commonly Scottish merchants but also those of other countries and trades. In Poland these people were called 'Scots', and were the second most common national minority (after Germans) by the seventeenth century (Krawczyk 2002). If Bonar is a family name, our author may even have been ultimately of Scottish descent himself (Burke \& Burke 1849: 27). From this perspective, we need not be surprised that Bonar is able to discuss Scotland. However, Bonar's knowledge of nature is unclear from this letter alone. On the one hand, Pliny's work was not widely trusted by dedicated naturalists, who used Aristotle's 'Historia Animalium' instead (Nauert 1979). By citing this book alone (VIII: 26-28), Bonar demonstrates a humanist education but a lack of formal training in natural history. Further, no lynx species has ever been native to Africa. The range of Lynx lynx covers Europe as well as Asia, so all the species mentioned here are genetically a single species, although the subspecies can be very different. It is however, only fair to point out that the countries Bonar names are not randomly chosen, they intentionally form a description of a continuous range for the lynx on a sixteenth century map, as per Fig. 1.

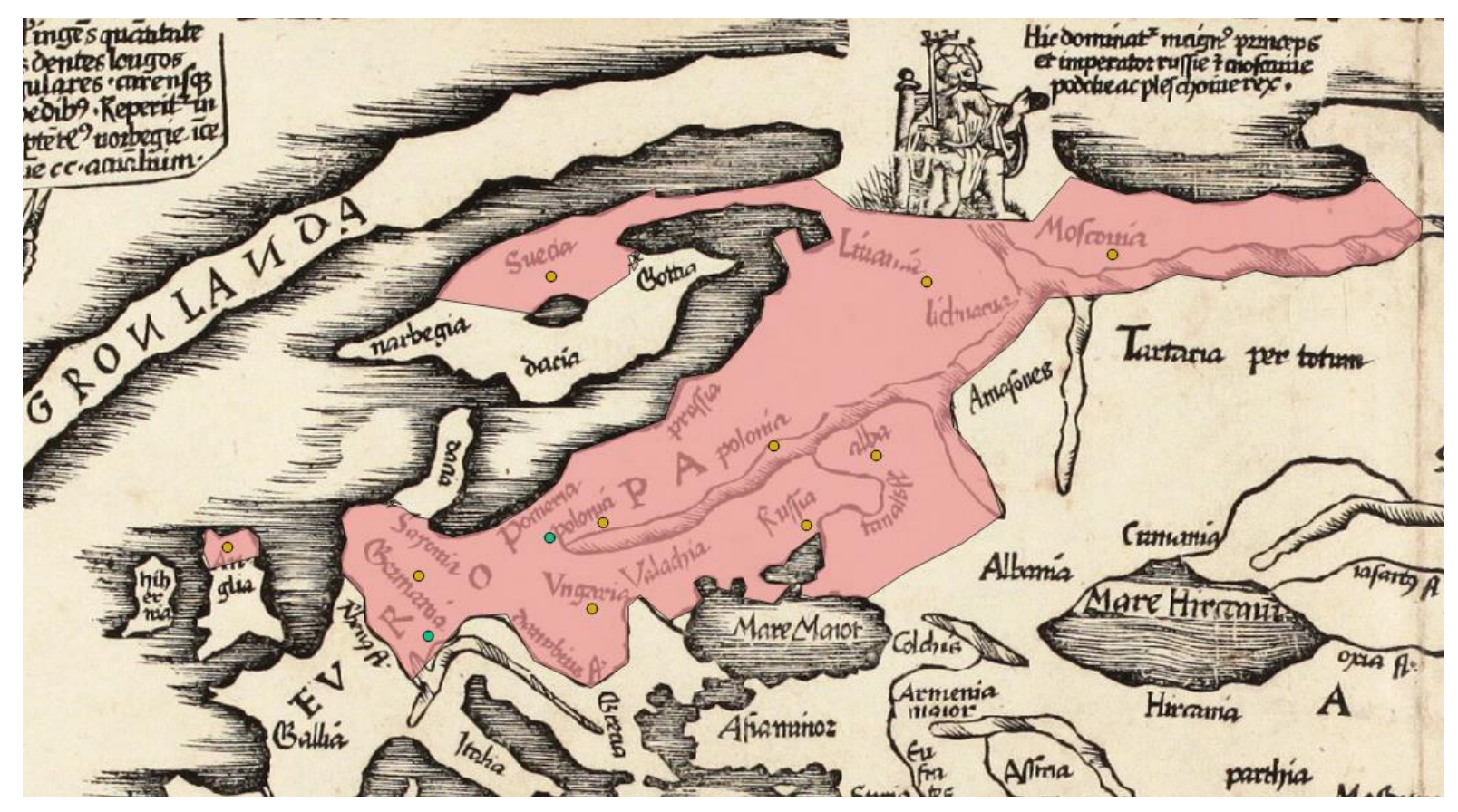

Fig 1. The sixteenth century range of the lox (Lynx lynx) according to Bonar of Balice. I have mapped the range onto Fries' world map of 1522 for clarity. Yellow dots highlight country names mentioned, green dots are the locations of the correspondents; Bonar and Gesner. 
Author's Manuscript (published in Archives of Natural History 44.2: 321-333) by Edinburgh University Press - please see final version on EUP website. (https://doi.org/10.3366/anh.2017.0452)

The idea that Bonar could have garbled the name Scotia or meant another country seems unlikely. Bonar (as quoted in Gesner) gives the term Scotia, which is most commonly applied to Scotland, but is also sometimes used to refer to the whole of Britain, Ireland or Nova Scotia. Of these, we can safely discount the last. The name Nova Scotia comes from the Scottish colonisation of that area, which was approved in 1621, well after our text was written (Nicholls 2010: 47). However, given the Polish practice of calling all British people 'Scots' (Krawczyk 2002) the term could have been loosely applied to the entirety of Britain or specifically Scotland or Ireland, although it is most customarily applied to Scotland. Gesner's natural history was translated by Edward Topsell into English in his History of Four-Footed Beasts in 1608, and Bonar's Scotia was there translated to 'Scotland' (p.491), confirming that he understood the name to refer to the usual place.

In later times, Buffon (1749, IX, p.238) offers a similar statement to Bonar, commenting: 'les plus belles peaux de loup-cervier viennent de la Sibérie'. This offers the possible solution that Bonar may have intended to write Siberia rather than Scotia. However, this comes 200 years after Bonar wrote, and I cannot find a similar phrase in any earlier natural history. Without any evidence to the contrary, we are not justified in amending the text.

As I see it, there are two further possible explanations for this statement. First, Bonar could have been correct, and Scotland could have maintained lynxes until the seventeenth century. Second, Bonar could have been talking about skins prepared in Scotland, but not hunted in Scotland. The remainder of this essay will discuss the evidence for each of these possibilities.

\section{Lynxes living wild in Scotland}

The most natural explanation of Bonar's writing would be if Scotland did still have a native population of lynxes. Every other country he mentioned was a known producer rather than simply a manufacturer of skins, and Scotland is represented as just the best of these.

On first consideration, this explanation may appear impossible. Scholars and the general public have tended not to think of the lynx as a recent native to Britain (Dent 1974: 84; Ritchie 1920: 111). However, recently lynx remains have been carbon dated to just 1,500 years ago, (cal. 425-600), meaning that the lynx went extinct in Britain during the historical period (Hetherington et al. 2006). This new conclusion has provoked re-examination of older evidence, providing, for example, a probable place name containing the Old English word for the lynx (lox) (Gelling 2006: 153). There are 
Author's Manuscript (published in Archives of Natural History 44.2: 321-333) by Edinburgh University Press - please see final version on EUP website. (https://doi.org/10.3366/anh.2017.0452)

also some potential references in poetry (Edel 1983; Hetherington 2010). As yet though, there is little convincing evidence which is securely dated to later than the year 650 and none original to the second millennium: The idea that the Old Irish word 'lug' (hero) might also/initially have been used for the lynx (Edel 1983; Hetherington 2010; Pedersen 1913: 186) has long been debunked (see especially: Chadwick 1935) and the sense is no longer included in the standard Dictionary of the Irish Language. The idea that Pictish art might also conceal lynxes (Hetherington 2010) is also insecure, considering the medieval tendency towards derivative rather than naturalistic art (Backhouse 1989; Raye 2013).

Still, the idea of a longer survival in Scotland than in south Britain would not be unusual in itself. Many of Britain's extirpated and declining mammal species have survived better in Scotland than in south Britain. The beaver (Castor fiber) undoubtedly survived until the sixteenth century in Scotland, regardless of whether it survived past the twelfth or thirteenth century in south Britain (Manning et al. 2014; Raye 2014). The wolf (Canis lupus) seems to have survived for a few centuries longer in Scotland than in England (Yalden 1999: 161-2, 168); in Britain the wildcat (Felis sylvestris) today continues to exist (in low numbers) only in Scotland (Kitchener \& Daniels 2008) and the pine marten (Martes martes) is functionally extinct in Britain outside of Scotland apart from possible relict populations and the current restocking project in mid Wales (Balharry et al. 2008; MacPherson et al. 2014).

It is possible, although not probable, that the lynx could have survived without being mentioned in historical records. Arguably, this could happen because the lynx has a very low profile in the literature of many cultures, perhaps because it is solitary and avoids contact with humans (Breitenmoser 1998: 281; Hetherington 2008: 77-8, 2010). Certainly not all native species leave a trail in the historical record. For example, there are currently no known references to the pool frog (Pelophylax lessonae) before 1700 (Kelly 2004), but there are no known references this old to the (definitely native) natterjack toad (Bufo calamita) either (Snell 1994). In this case, absence of evidence is not evidence of absence. However, this argument almost seems to be a reversal of the burden of proof when applied to a species like the lynx which we know did become extinct at some point in the period.

Luckily, we need not make the lynx invisible to hypothesise its survival. I recently made a directed search for medium and large terrestrial mammals through as much of the reliable historical tradition as I could access from 1188-1682 (Raye 2014). None of these sources gave reliable references to 
Author's Manuscript (published in Archives of Natural History 44.2: 321-333) by Edinburgh University Press - please see final version on EUP website. (https://doi.org/10.3366/anh.2017.0452)

wild populations of lynxes by name, but lynxes could potentially have been included under a different species name. Edel (1983) has suggested that portrayals of the last lynxes could hide behind references to lions. I did not find any wild 'lions' mentioned in my sources either, but I did find that cats were common in every period. The generic term cat (also catt, felis, cait) was fairly generic in the medieval period and the polecat (Mustela putorius) and pine marten were often considered types of cat along with the feral cat (Felis catus) and wildcat (Felis sylvestris) (Lovegrove 2007: 75, 203. Also see Oxford English Dictionary). It is conceivable that this term might have included the lynx also. There are analogue cases of the use of the term cat for other large felids: The term catamount today usually refers to the puma (Puma concolor). Further back, The Middle English Dictionary collects five records to the 'cat of the mountain' from the fifteenth century. Two of these (MS Arms. 58 and Brogyntyn 2.1 - apparently unedited hunting manuals) gloss the term as bad (felis sylvestris) but the term is also glossed twice in the 'Polychronicon' as pardus (leopard; Panthera pardus). Topsell (1607, p.577) corroborates this approach in the early modern period, explaining that the 'Leopard... in England is called a Cat of the Mountain'. The most plausible way to argue that populations of lynxes were still living, native, in Scotland in the sixteenth century is to assume that records of lynxes have, until now, been hidden behind records of cats.

So far we have examined evidence that suggests the lynx could have survived in Britain. There is also some evidence that suggests that the lynx actually did survive in Britain through the first half of the second millennium, although no other sources are as convincing as Bonar's statement at the beginning of this essay. For example, Hetherington (2010) points to a statement in Holinshed's Chronicles of England, Scotland and Ireland (1577, I:3), that Scotland once had wild lions with 'manes of great force'. This part of the text was written by William Harrison and is dubious because apart from lynxes not having manes, it also describes Scotland as having wild bulls. This is an old myth, perhaps based on the supposedly wild, white park cattle which were kept even in the early modern period (Hemming 2002). The reference was more probably intended to impress English readers and distance Scotland from England. The passage has even been compared with accounts from Britain's recent mystery big cat folklore (Goss 1992). Holinshed's other potential references are just as unlikely. I was initially impressed by the following:

As for his deceits and crafts, he [Martine the pope's money collector] hath more varietie of them, than the cat of the mounteine hath spots in his skin, or the pecocke hath eies in his taile. (p.232)

Wildcats do not have spots, and nor do polecats or pine martens. Domestic and feral cats are not called cats 'of the mounteine'. Lynxes can have spots, and we saw the spots of the Scottish lynxes 
Author's Manuscript (published in Archives of Natural History 44.2: 321-333) by Edinburgh University Press - please see final version on EUP website. (https://doi.org/10.3366/anh.2017.0452)

were especially commented on by Bonar in the introduction. However, considering the evidence from Topsell that 'cat of the mountain' can mean leopard, that may be how we should understand this reference. Even if it is not, the appearance of a species in a metaphor would not necessarily make it a native, or even commonly seen, just as the peacock (Pavo cristatus) is not a native species, despite being described here.

English translations provide other possible source of evidence. The sixteenth century renaissance saw an increase in the amount of scientific material being translated into English. Some of this material described lynxes which were still common in some areas of the continent. For example, Gesner's Historia Animalium was translated into English by Edward Topsell (1607). Topsell included Bonar's remarks with an explanatory note:

Bonarus had oftentimes seene them [lynxes] hunted in Moschouia, Littuania, Pollonia, Hungaria, and Germany: But he commendeth aboue al other the Linxes of Scotland and Swesia, as most beautifull, hauing Triangular spots vpon theyr skinnes. But the Indian and Affrican Linxes, he saith haue round spots, sharpe-bristly-short-haire, and full of spots on all parts of their body, and therefore they are not so delicate as the Linxes of Europe, which with good cause he coniectureth to be the Linxe that Pliny speaketh of, and not vnlike to that which is bred in Italy. (Topsell 1607: 491)

Since Topsell was ostensibly updating this book, this would have been a good place to distance himself from the writer if he disagreed. He elsewhere adds, for example that despite what Gesner says, the wolf, the fishing dog and the pine marten are no longer found in England (Topsell 1607: $171,497,735)$; this last comment perhaps suggesting the pine marten was already in decline. On the other hand, it is not clear that he considered himself to be an expert on the fauna of Scotland (unlike the fauna of England) so he may have abstained from personally commenting on the matter. Unfortunately, we cannot take Topsell's silence on this matter as strong evidence. Similarly, 'The Master of Game' a fifteenth century hunting text was translated into English by Edward of Norwich, a duke of York. This is a close translation of the French 'Livre de Chasse' by Gaston Phoebus de Foix. Edward translates the section on 'chatz sauvaiges', which is predominantly about the lynx without editing it. It would be tempting to draw conclusions about this, but Edward also translates the section on the wolf (p.54), despite wolves having been extinct in England for a century before he wrote. The inclusion of material by translators is therefore insecure evidence.

Slightly better evidence is provided by Robert Sibbald in Scotia Illustrata (1684, II:3). Sibbald was a trained naturalist and draws on correspondents from across Scotland to help catalogue and describe the country's fauna. Initially he describes three cat species as living in Scotland. Each of these has its 
Author's Manuscript (published in Archives of Natural History 44.2: 321-333) by Edinburgh University Press - please see final version on EUP website. (https://doi.org/10.3366/anh.2017.0452)

own paragraph, as per Sibbald's typical style. There is the Felis (the domestic cat), Felis sylvestris (wildcat) and then the Felis syriaca (?Syrian cat?). Since Sibbald's other species are all native, this one seems out of place. Here is its short paragraph:

Felis syriaca multis punctis interstincta, ore torvo $\&$ toroso, pectore $\&$ pedibus amplis. (Sibbald, 1684, Il:3, p.11)

(The cat of Syria is dappled with many spots, with a savage and muscular jaw, [and] with a large chest and paws.)

Here, Sibbald seems to be drawing on Aldrovandus' De Quadrupedibus Digitalis Viviparis (1637, III:10; p.565-6). On the one hand, the wording of Aldrovandus' account ('ore toruus, pectore torosus, pedibus amplis') is very similar. This suggests we should consider Sibbald's statement here as a translation, like the above. However, Aldrovandus' Felis syriaca is a particular species of wildcat from Syria; it can be born in the tropics and have a gentle disposition or born in the north and be fierce. The most important aspects of the cat, according to Aldrovandus are not mentioned by Sibbald. Sibbald also does not tend to include species just because he finds them elsewhere; his emphasis is on describing species reliably reported to him in Scotland. From this perspective it is possible Sibbald, or one of his informants, just borrowed the name to describe a local kind of cat. Sibbald also adds a detail not found in Aldrovandus. He gives Felis syriaca spots, which could describe the lynx, and is once again especially reminiscent of Bonar's spotted Scottish lynx. Spots are unusual in a wildcat, although typical for feral cats (Daniels et al. 1998). After this paragraph however, Sibbald seems to return to discussing the wildcat. This means that he considered Felis syriaca to be a special type of wildcat just like Aldrovandus. At most optimistic we could interpret this evidence to suggest that Sibbald had received unclear reports about lynxes and interpreted them as strange wildcats.

Overall, previous studies show that the lynx survived until at least 600 in south Britain, and a case could be made that the lynx could have survived in Scotland much longer. However, other than the words of Bonar of Balice in the introduction, there is little positive evidence from early modern naturalists to support this theory. Sibbald gives the second best evidence for this theory, and it is ambiguous at best.

\section{Scotland as a fur-preparation centre}

An alternative interpretation for Bonar's comment comes from the idea that Scotland was a centre of fur preparation during the early modern period. Therefore, the evidence of lynx fur being 
Author's Manuscript (published in Archives of Natural History 44.2: 321-333) by Edinburgh University Press - please see final version on EUP website. (https://doi.org/10.3366/anh.2017.0452)

exported from Scotland could be explained if clothing items were simply manufactured and exported from there, made of imported fur.

This importation of foreign furs for work in Britain was common. Veale $(2003: 26-30,126)$ has written a history of the English fur trade and explains that although the best furs were caught in Scandinavia and eastern Europe, these were only preserved for shipment there. The real job of properly tawing, sewing together and fashioning these furs was done locally. The most high-status clothing especially was made-to-order. For England most of the work was done in London by the Skinner's Guild. There are records of tens of thousands of unprocessed furs entering London, mainly squirrel (Sciurus vulgaris). Lynx skins (called luzern/lucerve after medieval Latin lupus cervarius) were sometimes imported too, although this was not frequent (Veale 2003: 57, 158-61).

In Scotland, scholars (Lovegrove 2007: 25; Ritchie 1920: 155-6) have argued that Inverness was a rival fur-centre. This interpretation is based partially on the Latin evidence of Hector Boece (1526-7: preliminary 18, II:51) from Scotorum Historia, later translated into Scots by Bellenden (1537, pp.xxxiii-iv, 69-70) among others. Boece attests that German merchants once came to Scotland to purchase the skins of (native) martens and beavers. This evidence may be biased, considering Boece and Bellenden's interest in emphasising Scotland's natural riches, but Lovegrove and Ritchie cite quantitative confirmation of the importance of the fur industry in Scotland in various exportation records from Leith, from the Mar and Kellie papers and from the Fur Market of Dumfries (see: Service 1891). This evidence is all useful to corroborate Boece's story in part, but not worth examining in detail, because it all suffers from the same problem - this is evidence of fur exportation, but all the furs mentioned in it could have been obtained locally. Service collected records of hundreds of thousands of furs sold by the Fur Market of Dumfries. He did not find any exotic furs advertised, the furs were mainly rabbit (Oryctolagus cuniculus), brown hare (Lepus europaeus), polecat and otter (Lutra lutra). Furs came from rural Scotland and northern England and were sent to urban Scotland and England (Service 1891).

Ritchie (1920: 155-6) does mention one piece of evidence which provides evidence of the exportation of exotic furs. The fourteenth century 'Assisa de Tolloneis', preserved in the deceptivelycalled 'Assises of David' (Taylor 2012) from the Ayr Manuscript give the standard taxation rate due on each bundle of exported fur. These include native furs, but also two which could not have been obtained in Scotland: sabinorum (sable (Martes zibellina), which is native to eastern Europe) and gris (Sciurus vulgaris fur which is tinged grey, only obtained from squirrels living in northern Europe 
Author's Manuscript (published in Archives of Natural History 44.2: 321-333) by Edinburgh University Press - please see final version on EUP website. (https://doi.org/10.3366/anh.2017.0452)

(Veale 2003: 24)). These tolls are nearly identical to those found in the Northumberland Chartulary (Johnson 1925), and is not clear which version of the law is the older, but, either way there is evidence here of the re-exportation of exotic furs from northern Britain from the fourteenth century. However, the re-exportation of exotic furs may have been a medieval practice which died out before the early modern period. it is possible that furs were no longer being commonly reexported by the time Bonar wrote. A replacement act of the Scottish parliament from the fifteenth century (James VI: 1424/12) no longer mentions any exotic skins, and even bans the exportation of marten skins, presumably because they were high status and becoming rare.

None of the sources given above attest to Scotland specialising in lynx fur, but I have found some moderate evidence that it was well-known there. The corpus of the Dictionary of the Scots Language collects six passing attestations to 'lucerve' or 'lucerd' being used to line gowns in the sixteenth century (Veale talks more about this practice, 2003: 29). These all come from Treasury and Wardrobe accounts (1538-61), suggesting that lynx fur was popular in the Stuart court of James V and Mary I when Bonar wrote. We may compare this with the English evidence of John Caius in De rariorum animalium atque stirpium historia (1570 I:4). Caius starts by describing a lynx he saw in the Tower of London menagerie, but then makes an interesting remark in the conclusion:

Luzarne nostri vocant, lunciamne an lyncem ex vocum symphon a dicturt ambiguum est. Pellis in usu est magnatum, \& pretiis venditur amplioribus (Venn 1912: 30-1).

(Our people call it the luzarne, it is unclear whether it should be called luncia or lynce based on the closeness of the words. The pelt is used by nobles and sold at high prices.)

Clearly lynx fur was known and valued as a high status fur among the early modern elites of society across sixteenth century Britain.

Perhaps most importantly, there is evidence from shortly after Bonar wrote that lynx fur could have been shipped to Poland. As I explained in the introduction, Scottish merchants were common in Polish cities at the time. These merchants were known for importing their 'Scotswares', which were generally common household items, however they also occasionally included rarer items (Krawczyk 2002). A general edict was issued in 1551 against Jewish and Scottish merchants carrying 'all manner of fur garments and skins' and selling them to anyone (not just the rich) without demanding high taxes (Bajer 2012: 175, 180). The way this edict is worded suggests that the furs included were rare and exotic, breaking local sumptuary norms by allowing poorer people to dress in unusual furs. Lynx 
Author's Manuscript (published in Archives of Natural History 44.2: 321-333) by Edinburgh University Press - please see final version on EUP website. (https://doi.org/10.3366/anh.2017.0452)

'from Scotland' would be just such a fur. If Bonar obtained his courtly fur gowns or fine fur clothing from Scottish merchants he might well have imagined Scotland to produce excellent lynxes.

Taken together, there is evidence here that (i) exotic furs, including lynx skins were imported into Scotland in the sixteenth century, (ii) these were used to line gowns for the people of court, (iii) Scottish merchants exported some exotic fur clothes and skins into Poland for sale around this time period.

\section{Conclusion}

Bonar of Balice's assertion in Historia Animalium that Scotland 'produces the best lynxes' admits of at least two explanations. Either the lynx really did linger on in early-modern Scotland, or Scotland was a famous for exotic furs which it re-exported.

The first explanation is currently weak, and would need additional evidence before we could accept it. For example, if further archaeological evidence or evidence from a Scottish textual source was found, which attested the presence of the lynx in early modern Scotland, this would fully justify us to accept the first interpretation. My recent search of the Scottish corpus (Raye 2014) should have uncovered written evidence if it existed, but references may be hiding behind the term cat (especially cat of the mountain, wood cat) or felis in Latin.

Since our second interpretation relies on Bonar being mistaken about the presence of a Scottish lynx, it can only ever be a "most probable" interpretation. At present however, the explanation seems much stronger. There is evidence that lynx fur was used in high-status gowns in sixteenth century Scotland, and that Scotland had a strong fur industry. There is also evidence that exotic fur was commonly re-exported in the fourteenth century. Finally, there is evidence that Scottish merchants were importing high-status furs into Poland around the time Bonar wrote.

Most probably, the reason Bonar believed Scotland produced the best lynxes was because the best lynx furs he had ever seen were imported into Poland as 'Scotswares' by Scots, not because the lynx was actually still found there. 
Author's Manuscript (published in Archives of Natural History 44.2: 321-333) by Edinburgh University Press - please see final version on EUP website. (https://doi.org/10.3366/anh.2017.0452)

\section{Acknowledgements}

This paper owes special thanks to Barry Lewis and Cyril Edwards for their help with the Bonar translation. All errors are still mine. I also owe thanks to them and to Dylan Foster Evans for discussions about the evidence. It is based partly on work carried out for my master's degree at the University of Oxford and my doctoral research at Cardiff University; it undoubtedly draws on forgotten conversations at both institutions - thanks to all involved.

\section{Notes}

[1] The original letter from Bonar to Calvin is enclosed in Geneva MS. Lat. 109, but there is an edition in the Corpus Reformatorum series: (Baum et al. 1877: 149-50). Bonar was succeeded by Stanislav Szafranietz, claimant to the Polish throne in place of Henry de Valois (1574), and also a keen Reformer (Krasinski 1838: 223).

[2] See Wheelock's Latin, Chapter IX for more on the distinction between iste and ille in Latin. Generally ille is the more normal demonstrative ('that one') whereas iste has the force of 'that one of yours'. With the Constantinople lynx the term probably indicates a picture in Gesner's Icones Animalium, but in the rest of the passage it is often altered to 'ours' when combined with noster.

\section{References}

\section{Primary Sources}

Acts of the Parliaments of Scotland (vol. 1). James I: 1424/12. 'Off the custumis of diverse wild best skynnis'.

Baillie-Grohman, F., \& WilLIAM, A. 1909 The master of game: the oldest English book on hunting/by Edward, Second Duke of York. London.

BAUM, G., CUNITZ, E., \& ReUSS, E. 1877 loannis Calvini: Opera (vol. 16). Corpus Reformatorum 44.

BufFon, G. 1749 Histoire Naturelle (vol. 9). Paris.

FRIES, L. 1535 Nova Orbis Hydrographorum ab eo quem Ptolomeus Posuit. Lyon.

GESNER, C. 1602-3 Historiae Animalium (vol. 1). Frankfurt.

The Holinshed Project 2008-13 Chronicles of England, Scotland and Ireland, 1587 ed. (vol. 1). (Oxford University, www.cems.ox.ac.uk/holinshed/, accessed 11/6/16)

JOHNSON, C. 1925 The oldest version of the customs of Newcastle-upon-Tyne. Archaeol Aeliana, 4th Series 1: 169-178.

MAITLAND, T. 1821 The History and Chronicles of Scotland (vol. 1). Edinburgh.

RACKHAM, M. A. 1967 Pliny, Natural History. London.

SIBBALD, R. 1684 Scotia Illustrata. Edinburgh.

SUTTON, D. 2010 Hector Boece: Scotorum Historia (1575 version) (hypertext critical edition, http://www.philological.bham.ac.uk/boece/, accessed: 11/6/16)

TOPSELL, E. 1607 The History of Four-Footed Beasts, Serpents and Insects. London.

VenN, J. 1912 The Works of John Caius. Cambridge.

\section{Secondary Sources}


Author's Manuscript (published in Archives of Natural History 44.2: 321-333) by Edinburgh University Press - please see final version on EUP website. (https://doi.org/10.3366/anh.2017.0452)

BACKHOUSE, J., 1989 Birds, beasts and initials in Lindisfarne's Gospel books. pp.165-188. in Bonner, G., Rollason, D., and Stancliffe, C. (editors), St Cuthbert, His Cult and His Community to AD 1200. Woodbridge.

BAJER, P. P., 2012 Scots in the Polish-Lithuanian Commonwealth, 16th to 18th centuries: The formation and disappearance of an ethnic group. Leiden.

BalharRY, E. A.,, JefFries, D. J., AND BIRKS, J. D. S., 2008 Pine marten. Mammals of the British Isles: handbook, 4th edn. The Mammal society, London.

BREITENMOSER, U., 1998 Large predators in the Alps: the fall and rise of man's competitors. Biological conservation 83: 279-289.

BURKE, J., AND BURKE, J. B., 1849 A Dictionary of the Landed Gentry of Great Britain and Ireland. London.

CHADWICK, N. K., 1935 Lug Scéith Scál Find - Elegy on Labraid Loingseach. Scottish Gaelic Studies 4: 15.

Daniels, M. J., BalmarRY, D.,, HIRST, D., ET AL., 1998 Morphological and pelage characteristics of wild living cats in Scotland: implications for defining the 'wildcat'. Journal of Zoology 244: 231-247.

DENT, A., 1974 Lost beasts of Britain. London.

EDEL, D., 1983 Geoffrey's So-Called Animal Symbolism and Insular Celtic Tradition. Studia Celtica 18: 96-110.

GeluING, M., 2006 The Place-names of Shropshire, vol. 82. Nottingham.

Goss, M., 1992 Alien Big Cat Sightings in Britain: A Possible Rumour Legend? Folklore 103: 184-202.

HEMMING, J., 2002 Bos primigenius in Britain: Or, why do fairy cows have red ears? Folklore 113: 7182.

HETHERINGTON, D. A., 2008 The history of the Eurasian Lynx in Britain and the potential for its reintroduction. British Wildlife 20: 77-86.

Hetherington, D. A., 2010 The Lynx. in O'Connor, T., and Sykes, N. J. (editors), Extinctions and Invasions. Oxford.

Hetherington, D. A., LORD, T. C., AND JACOBI, R. M., 2006 New evidence for the occurrence of Eurasian lynx (Lynx lynx) in medieval Britain. Journal of Quaternary Science 21: 3-8.

JoHnson, C., 1925 The oldest version of the customs of Newcastle-upon-Tyne. Archaeol Aeliana, 4th series 1: 169-178.

KELLY, G., 2004 Literature/archive search for information relating to pool frogs Rana lessonae in East Anglia. Peterborough.

KitChener, A. C., AND DANIElS, M. J., 2008 The Wildcat. pp.397-406. in Harris, S., and Yalden, D. W. (editors), Mammals of the British Isles: Handbook, 4th Edition. Southampton.

KONECZNY, F., 1924 Dzieje administracji w Polsce w zarysie.

KrasinSKI, W. S., 1838 Historical Sketch of the Rise, Progress and Decline of the Reformation in Poland, vol. 1. London.

KraWCZYK, A., 2002 The British in Poland in the seventeenth century. The Seventeenth Century 17: 254-272.

LOVEGROVE, R., 2007 Silent fields: the long decline of a nation's wildlife.

MacPherson, J., Croose, E.,, BAvin, D., et Al., 2014 Feasibility Assessment for Reinforcing Pine Marten Numbers in England and Wales. Eastnor. 
Author's Manuscript (published in Archives of Natural History 44.2: 321-333) by Edinburgh University Press - please see final version on EUP website. (https://doi.org/10.3366/anh.2017.0452)

MANNING, A. D.,, COLES, B. J.,, LUNN, A. G., ET AL., 2014 New evidence of late survival of beaver in Britain. The Holocene 24: 1849-1855.

NAUERT, C. G., 1979 Humanists, scientists, and Pliny: changing approaches to a classical author. The American historical review 84: 72-85.

NiCHOLLS, A., 2010 A Fleeting Empire: Early Stuart Britain and the Merchant Adventurers to Canada.

OGILVIE, B. W., 2008 The science of describing: Natural history in Renaissance Europe. Chicago.

PederSEN, H., 1913 Vergleichende Grammatik der keltischen Sprachen, vol. 1.

PINON, L., 2005 Conrad Gessner and the historical depth of Renaissance natural history. pp.241-267. in Pomata, G., and Siraisi, N. G. (editors), Historia: Empiricism and erudition in early Modern Europe. Cambridge.

RAYE, L., 2013 Lions in Insular British Artwork, 650-1000 AD. JLARC 7: 72-89.

RAYE, L., 2014 The early extinction date of the beaver ( Castor fiber ) in Britain. Historical Biology 27: 1029-1041.

RITCHIE, J., 1920 The Influence of Man on Animal Life in Scotland. Cambridge.

SERVICE, R., 1891 The Old Fur Market of Dumfries. The Scottish Naturalist 33: 97-102.

SNELL, C., 1994 The pool frog: a neglected native? British Wildlife 5: 1-4.

TAYLOR, A., 2012 The Assizes of David I, King of Scots, 1124-53. Scottish Historical Review 91: 197238.

TOPSELL, E., 1607 The History of Four-Footed Beasts, Serpents and Insects. London.

VEALE, E. M., 2003 The English fur trade in the later Middle Ages, vol. 38. Loughborough.

YALDEN, D., 1999 The history of British mammals. Cambridge. 